\title{
Thiol peroxidase-like activity of some intramolecularly coordinated diorganyl diselenides ${ }^{\#}$
}

\author{
SANGIT KUMAR and HARKESH B SINGH* \\ Department of Chemistry, Indian Institute of Technology Bombay, Powai, Mumbai 400 076, India \\ e-mail: chhbsia@chem.iitb.ac.in
}

MS received 19 April 2005; revised 11 November 2005

\begin{abstract}
Several new diaryl diselenides having intramolecular coordinating groups have been synthesized by ortho-lithiation/ $\mathrm{Na}_{2} \mathrm{Se}_{2}$ routes in good yield. Bis[2-(N-phenylferrocenecarboxamide)] diselenide (10), bis[2-(N-tert-butylferrocenecarboxamide)] diselenide (11), $(S)(S)$-bis[2(- $N$-phenethylferrocenecarboxamide)] diselenide (12) were synthesized by the ortho-lithiation route. Bis[2-(N,N-dimethylaminomethylnaphthyl)] diselenide (13) was synthesized by lithium/bromide exchange reaction whereas bis(2,4-dinitrophenyl) diselenide (14) was prepared by the reaction of disodium diselenide with 2,4dinitro-1-chlorobenzene. Thiol peroxidase-like activities of the diorganodiselenides have been evaluated by using $\mathrm{H}_{2} \mathrm{O}_{2}$ as substrate and $\mathrm{PhSH}$ as cosubstrate. Diselenides (13) and (14) with dimethylaminomethyl- or nitro-donor groups in close proximity to selenium, show much better thiol peroxidase-like activities compared to diselenides 10-12 with amide donor groups. Cyclic voltammetry study of diselenides 10-12 derived from redox-active ferrocenamide has been carried out.
\end{abstract}

Keywords. Selenium; diorganodiselenide; ferrocenamide; thiol peroxidase; antioxidant.

\section{Introduction}

Glutathione peroxidase is a selenoenzyme, which is well known for its antioxidant function. This selenoenzyme catalyses the reduction of various harmful peroxides produced in biological systems and protects the cell from oxidative stress. ${ }^{1}$ The enzyme (Enz$\mathrm{SeH})$ reduces the peroxides to the corresponding alcohol or water and in the process gets converted to the corresponding selenenic acid (Enz-SeOH). The cofactor glutathione (GSH) is next introduced into the enzyme forming the Enz-SeSG complex, which then reacts with a second molecule of GSH to regenerate the reduced enzyme (Enz-SeH) and the oxidized disulphide product, GSSG (Scheme 1). ${ }^{2}$

A variety of small organoselenium compounds have been reported as mimics of glutathione peroxidase enzyme (chart 1). ${ }^{3}$ These include N-Se heterocycles, ${ }^{4,5}$ recently reported $\mathrm{Se}-\mathrm{O}$ heterocycles, ${ }^{6,7}$ artificial selenoenzyme selenosubtilisin ${ }^{8}$ selenopeptides, ${ }^{9}$ variously substituted diselenides, ${ }^{10}$ and their tellurium analogues. ${ }^{11,12}$ We have previously reported the thiol

\footnotetext{
*For correspondence

"Dedicated to the memory of the late Professor Bhaskar G Maiya
}

peroxidase-like activities of a range of intramolecularly coordinated diorganodiselenides (1-9) (chart 1). ${ }^{10 \mathrm{c}, 10 \mathrm{~d}, 10 \mathrm{e}}$ It was observed that the diselenides (1-2) with basic tert-aminoferrocenyl coordinating groups, showed much better thiol peroxidase-like activity compared to other related diselenides.

In this context, we contemplated investigating the thiol peroxidase-like activity of other related diselenides based on ferrocene. ${ }^{13}$ In this paper, we report the synthesis, characterization and thiol peroxidaselike activity of ferrocenamide-based diselenides (10-12). In our earlier study, it was further observed that diselenide $\mathbf{3}$ with a non-conjugated amine

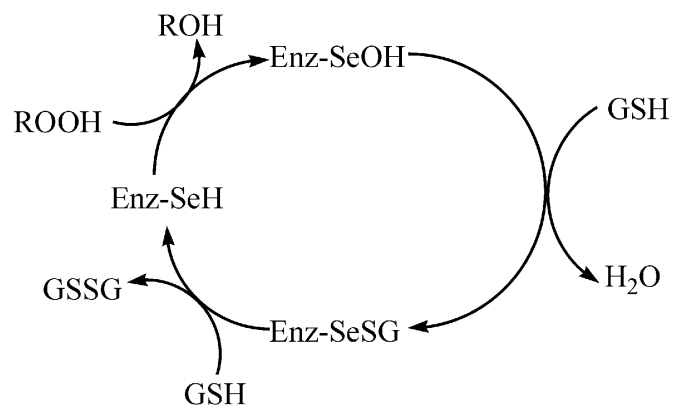

Scheme 1. Catalytic mechanism of glutathione peroxidase enzyme. 


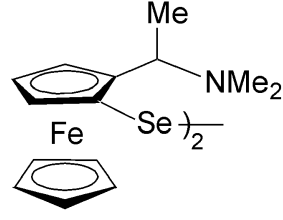

$1=R, S$

$2=S, R$<smiles>O=S(=O)(O)c1ccccc1C1=NCCCO1</smiles>

8

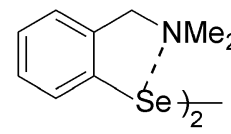

3

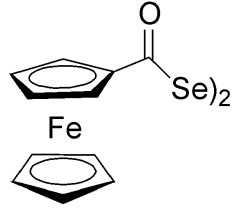

9

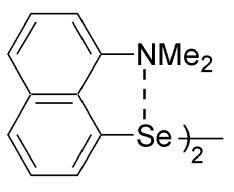

4

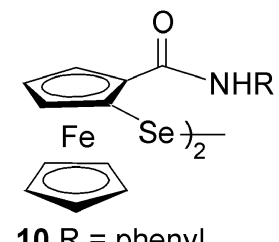

phenyl

$11 \mathrm{R}=$ tert-butyl

$12 \mathrm{R}=(S)$-phenethyl<smiles>[R]C1([R])COC(c2ccccc2S(=O)(=O)O)=N1</smiles>

$5=\mathrm{R}_{1}=\mathrm{R}_{2}=\mathrm{H}$

$6=\mathrm{R}_{1}=\mathrm{R}_{2}=\mathrm{CH}_{3}$

$7=\mathrm{R}_{1}=\mathrm{H}, \mathrm{R}_{2}=\mathrm{Et}$

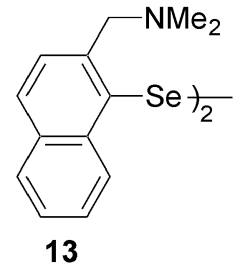<smiles>O=[N+]([O-])c1ccc(S(=O)(=O)[O-])c([N+](=O)[O-])c1</smiles>

14

Chart 1. Diorganodiselenides as thiol peroxidase mimics.

group, exhibited significant thiol peroxidase-like activity whereas deselenide $\mathbf{4}$ with a conjugated amine donor group was inactive under identical conditions. To delineate the effects of conjugated and non-conjugated $\mathrm{N}, \mathrm{N}^{\prime}$-dimethylamino groups, we decided to prepare and study the thiol peroxidase-like activity of $\mathbf{1 3}$ which has both the naphthyl group and the non-conjugated amino group. Thiol peroxidase-like activity of diselenide $\mathbf{1 4}$ with an ortho-coordinating nitro group is also compared.

\section{Experimental section}

\subsection{Materials}

Ferrocene carboxylic acid was prepared from ferrocene by following the literature method. ${ }^{14}$

2.1a General procedures: All reactions were carried out under nitrogen or argon using standard vacuumline techniques. Solvents were purified by standard procedures and were freshly distilled prior to use. Melting points were recorded in capillary tubes and are uncorrected. IR spectra were recorded as $\mathrm{KBr}$ pellets on a Nicolet Impact 400 FTIR spectrometer. ${ }^{1} \mathrm{H}$ and ${ }^{13} \mathrm{C}$ NMR spectra were obtained in $\mathrm{CDCl}_{3}$ on a Varian VXR 300S spectrometer. ${ }^{1} \mathrm{H}$ chemical shifts are cited with respect to $\mathrm{SiMe}_{4}$ as internal standard. The ${ }^{77} \mathrm{Se}$ spectra were obtained at $95.35 \mathrm{MHz}$ in $\mathrm{CDCl}_{3}$ on a Bruker AMX500 spectrometer using di- phenyl diselenide as external standard. Chemical shifts are reported relative to dimethyl selenide $\left({ }^{77} \mathrm{Se}\right)$ $(0 \mathrm{ppm})$ by assuming that the resonance of the standard is at 461 respectively. Elemental analyses were performed on a Carlo-Erba model 1106 elemental analyser. Optical rotations were measured using a Jasco Model DIP 370 digital polarometer. Electrospray mass spectra (ES-MS) were performed at room temperature on a Q-Tof micro (YA-105) mass spectrometer. FAB mass spectra were recorded on a Jeol SX 102/DA-6000 mass spectrometer/data system using argon/xenon $(6 \mathrm{kv}, 10 \mathrm{~mA})$ as the FAB gas. The accelerating voltage was $10 \mathrm{kV}$ and the spectra were recorded at room temperature. $m$-Nitrobenzyl alcohol NBA was used as the matrix unless specified otherwise. The matrix peak may appear at $\mathrm{m} / \mathrm{z}$ $136,137,154,289,307$ in the absence of any metal ions. If metal ions such as $\mathrm{Na}^{+}$are present these peaks may be shifted accordingly. For isotopes the value given is for the most intense peak. Cyclic voltammetry: CH I660 scanning potentiostat; Pt working and auxiliary electrodes; $\mathrm{Ag} / \mathrm{Ag}^{+}\left(0 \cdot 1 \mathrm{M} \mathrm{AgNO}_{3}\right.$ in $\left.\mathrm{CH}_{3} \mathrm{CN}\right)$ as reference electrode; $0 \cdot 1 \mathrm{M}\left[\mathrm{NBu}_{4}\right]\left[\mathrm{ClO}_{4}\right]$ in $\mathrm{CH}_{3} \mathrm{CN}$ as a supporting electrolyte; scan rate $200 \mathrm{mV} \mathrm{s}^{-1}$; under these condition $\left[\mathrm{Fe}\left(\mathrm{C}_{5} \mathrm{H}_{5}\right)_{2}\right] /$ $\left[\mathrm{Fe}\left(\mathrm{C}_{5} \mathrm{H}_{5}\right)_{2}\right]^{+}$has $E_{1 / 2}$ of $+0.060 \mathrm{~V}$.

2.1b Synthesis of $N$-phenylferrocenecarboxamide (15): ${ }^{15}$ To a stirred solution of ferrocene carboxylic acid $(2.30 \mathrm{~g}, 10 \mathrm{mmol})$ in $\mathrm{CH}_{2} \mathrm{Cl}_{2}(10 \mathrm{ml})$ was added 
oxalyl chloride $(1.32 \mathrm{ml}, 15 \mathrm{mmol})$ via syringe at room temperature under nitrogen. Gas evolution was accompanied by the formation of a dark red coloured homogeneous solution. After $30 \mathrm{~min}$, solvent was removed under vacuo. The resultant crude ferrocenoyl chloride was isolated as a red oil that crystallized on standing. It was taken up in $\mathrm{CH}_{2} \mathrm{Cl}_{2}(20 \mathrm{ml})$ and added via syringe to a solution of phenyl amine $(0.93 \mathrm{~g}, 10 \mathrm{mmol})$ and triethyl amine $(2.1 \mathrm{ml}$, $15 \mathrm{mmol}$ ) under nitrogen at $0^{\circ} \mathrm{C}$. The reactiom mixture was stirred overnight. The dark red coloured reaction mixture was washed with $2 \times 50 \mathrm{ml}$ of water extracted with $2 \times 50 \mathrm{ml}$ of $\mathrm{CH}_{2} \mathrm{Cl}_{2}$, dried over $\mathrm{Na}_{2} \mathrm{SO}_{4}$ and concentrated under vacuo. The crude product was purified by column chromatography using $\mathrm{SiO}_{2}\left(60-120\right.$ mesh) and $\mathrm{CH}_{2} \mathrm{Cl}_{2} / \mathrm{CH}_{3} \mathrm{OH}(9 \cdot 8: 0 \cdot 2)$ to give compound $\mathbf{1 5}$ as a yellow crystalline powder. Yield: 2.85 g (93.4\%), m.p. $200-202^{\circ} \mathrm{C}$; Anal. Calcd. for $\mathrm{C}_{17} \mathrm{H}_{15} \mathrm{FeNO}$ : C, 66.91; H, 4.95; N, 4.58\%; Found: C, 66.59, H, 4.95; N, 4.81\%; IR (KBr): 3294, 3085, 2921, 1642, 1313, $696\left(\mathrm{~cm}^{-1}\right) ;{ }^{1} \mathrm{H}$ NMR $\left(\mathrm{CDCl}_{3}\right) \delta$ $4.26(s, 5 \mathrm{H}), 4.44(t, 2 \mathrm{H}), 4.78(t, 2 \mathrm{H}), 7.08-7 \cdot 16$ $(m, 1 \mathrm{H}), 7 \cdot 32-7 \cdot 41(m, 2 \mathrm{H}), 7 \cdot 56-7 \cdot 64(m, 2 \mathrm{H})$.

2.1c Synthesis of N-tert-butylferrocenecarboxamide (16): ${ }^{15}$ Ferrocenecarboxamide (16) was synthesized by a similar method to that described for $\mathbf{1 5}$ at 15 mmol scale. The standard workup gave the crude product, which was purified by column chromatography using $\mathrm{SiO}_{2}$ (60-120 mesh) and $\mathrm{CH}_{2} \mathrm{Cl}_{2} / \mathrm{CH}_{3} \mathrm{OH}$ (9.8: $0 \cdot 2)$ to give compound $\mathbf{1 6}$ as a yellow crystalline powder. Yield: $3.93 \mathrm{~g}(93 \%)$, m.p. $205-208^{\circ} \mathrm{C}$; Anal. Calcd. for $\mathrm{C}_{15} \mathrm{H}_{19}$ FeNO: C, 63.17; H, 6.72; N, 4.91\%; Found: C, 62.87, H, 6.58; N, 5.17\%; IR (KBr): $3315,3079,2973,1630,1551,1453,1308,1222$, $821\left(\mathrm{~cm}^{-1}\right) ;{ }^{1} \mathrm{H}$ NMR $\left(\mathrm{CDCl}_{3}\right) \delta 1.44(s, 9 \mathrm{H}), 4.32(t$, $3 \mathrm{H}), 4.65(t, 2 \mathrm{H}) ; 5.4($ broad $d, 1 \mathrm{H}), \mathrm{GC}$ retention time $=12.97 \mathrm{~min}$, GC-MS (\% abundance $): 285$ (85\%), 229 (100\%), 211 (50\%), 137 (60\%).

2.1d Synthesis of (S)-N-phenethylferrocenecarboxamide (17): ${ }^{16}$ Ferrocenecarboxamide (17) was prepared by a similar method to that described for $\mathbf{1 5}$ at $2 \mathrm{mmol}$ scale. The crude product was purified by column chromatography using $\mathrm{SiO}_{2}$ (60-120 mesh) and $\mathrm{CH}_{2} \mathrm{Cl}_{2} / \mathrm{CH}_{3} \mathrm{OH}(9 \cdot 8: 0 \cdot 2)$ to gave compound 17 as a yellow crystalline powder. Yield: $0.6 \mathrm{~g}(90 \%)$, m.p. $198-202^{\circ} \mathrm{C} ;[\alpha]=+34.99\left(0 \cdot 1 \mathrm{c}, \mathrm{CHCl}_{3}\right)$; Anal. Calcd. for $\mathrm{C}_{17} \mathrm{H}_{15} \mathrm{FeNO}$ : C, 68.48; H, 5.74; N, 4.20\%. Found: C, 68.37, H, 4.95; N, 4.81\%. IR (KBr): 3310, 3085, 2921, 1642, 1313, $696\left(\mathrm{~cm}^{-1}\right) .{ }^{1} \mathrm{H}$ NMR
$\left(\mathrm{CDCl}_{3}\right) \delta 1.56(d, 3 \mathrm{H}), 4 \cdot 11(s, 5 \mathrm{H}), 4 \cdot 31(t, 2 \mathrm{H})$, $4.61(d, 1 \mathrm{H}), 4.67(d, 1 \mathrm{H}), 5.28(m, 1 \mathrm{H}), 5.82(d$, $1 \mathrm{H}), 7 \cdot 27(m, 1 \mathrm{H}),, 7 \cdot 37(m, 4 \mathrm{H}) ;{ }^{13} \mathrm{C}$ NMR $\left(\mathrm{CDCl}_{3}\right)$ : $\delta 21 \cdot 7,48 \cdot 5,67 \cdot 83,68 \cdot 41,69 \cdot 28,70 \cdot 43,70 \cdot 44,76 \cdot 07$, 126.42, 127.4, 128.7, 143.6, 169.3. ES-MS: $\mathrm{m} / \mathrm{z}=$ $333(100)\left[M^{+}\right]$.

2.1e Synthesis of bis[2-(N-phenyl ferrocenylcarboxamide)] diselenide (10): To a stirred solution of ferrocenecarboxamide $15(0.61 \mathrm{~g}, 2 \mathrm{mmol})$ in dry THF (35 ml) under $\mathrm{N}_{2}$ at $0^{\circ} \mathrm{C}$ was added $n$-BuLi ( $2.25 \mathrm{ml}, 4.2 \mathrm{mmol}, 1.6 \mathrm{M}$ solution in hexane) dropwise $(\approx 1$ drop/10 s). A dark red coloured, homogenous solution of dianion (18) was formed after $40 \mathrm{~min}$. Elemental selenium $(0.16 \mathrm{~g}, 2 \mathrm{mmol})$ was added to the resulting reaction mixture under a brisk flow of $\mathrm{N}_{2}$ to exclude the air. The selenium powder was consumed rapidly to give a homogeneous solution of blackish red coloured lithium selonolate (19). The reaction mixture was poured into saturated aqueous solution of $\mathrm{K}_{3} \mathrm{Fe}(\mathrm{CN})_{6}(0.85 \mathrm{~g}, 2.5 \mathrm{mmol})$, and then placed in a separating funnel and extracted with $\mathrm{CH}_{2} \mathrm{Cl}_{2}(2 \times 25 \mathrm{ml})$. Standard work up, followed by column chromatography using $\mathrm{SiO}_{2}$ (60-120 mesh), $\mathrm{CH}_{2} \mathrm{Cl}_{2} / \mathrm{CH}_{3} \mathrm{OH}(18: 2)$ gave a red colour solid. Recrystallisation from $\mathrm{CH}_{2} \mathrm{Cl}_{2} / \mathrm{CH}_{3} \mathrm{OH}$ afforded dark red coloured crystals. Yield: $0.52 \mathrm{~g}$ (68\%), m.p. 138-140 ${ }^{\circ} \mathrm{C}$; Anal. Calcd. for $\mathrm{C}_{34} \mathrm{H}_{28} \mathrm{Fe}_{2} \mathrm{~N}_{2} \mathrm{O}_{2} \mathrm{Se}_{2}$ : C, 53.32; H, 3.68; N, 3.65\%. Found: C, 52.48, H, 3.71; N, 3.28\%; IR (KBr): 3302, 3093, 2927, 2855, 1657, $1604,1532,1440,1249,762\left(\mathrm{~cm}^{-1}\right) .{ }^{1} \mathrm{H}$ NMR $\left(\mathrm{CDCl}_{3}\right)$ $\delta 4.21(\mathrm{~s}, 10 \mathrm{H}), 4.34-4.56(\mathrm{~m}, 4 \mathrm{H}), 5 \cdot 04-5 \cdot 10(\mathrm{~m}$, $2 \mathrm{H}), 7 \cdot 06-7 \cdot 14(m, 4 \mathrm{H}), 7 \cdot 26-7 \cdot 36(m, 4 \mathrm{H}), 7 \cdot 48(d$, $2 \mathrm{H}), 9.07(d, 2 \mathrm{H}) ;{ }^{13} \mathrm{C} \mathrm{NMR}\left(\mathrm{CDCl}_{3}\right): \delta 71 \cdot 3,71 \cdot 49$, $72 \cdot 03,72 \cdot 65,72 \cdot 85,73 \cdot 65,80 \cdot 39,119 \cdot 6,123 \cdot 8,128 \cdot 8$, 167.8. ${ }^{77} \mathrm{Se} \mathrm{NMR}\left(\mathrm{CDCl}_{3}\right) \delta 484,489$; MS (FAB): $m / z 768\left(M^{+}\right), 701,613,460,307,289,165,154,138$, 120, 107.

2.1f Synthesis of bis[2-(N-tert-butylferrocene carboxamide)] diselenide (11): Compound $\mathbf{1 1}$ was synthesized as described for $\mathbf{1 0}$, from N-tertbutylferrocenylcarboxamide at $2 \mathrm{mmol}$ scale and purified by column chromatography by using $\mathrm{SiO}_{2}$ (60-120 mesh), $\mathrm{CH}_{2} \mathrm{Cl}_{2} / \mathrm{CH}_{3} \mathrm{OH}(15: 2)$ to give red coloured solid. Recrystallization from $\mathrm{CH}_{2} \mathrm{Cl}_{2}$ and hexane afforded dark red coloured crystals. Yield: $0.51 \mathrm{~g},(71 \%)$, m.p. $142-145^{\circ} \mathrm{C}$; Anal. Calcd. for $\mathrm{C}_{30} \mathrm{H}_{36} \mathrm{Fe}_{2} \mathrm{~N}_{2} \mathrm{O}_{2} \mathrm{Se}_{2}$ : C, 49.64; $\mathrm{H}, 4.99$; N, 3.85\%. Found: C, 50.87, H, 5.79; N, 3.42\%. IR (KBr): 3342, 2967, 2987, 2855, 1670, 1644, 1525, 1466, 1229, 
$815\left(\mathrm{~cm}^{-1}\right) .{ }^{77} \mathrm{Se}$ NMR $\left(\mathrm{CDCl}_{3}\right) \delta$ 450, 457; MS (FAB): $m / z 726\left(M^{+}\right)$.

2.1g Synthesis of $(S, S)$ bis[2-(N-phenethylferrocene carboxamide)]diselenide (12): Diselenide (12) was prepared similarly as described for related diselenide (10) at $2 \mathrm{mmol}$ scale. The oxidized product was purified by column chromatography using $\mathrm{SiO}_{2}$ (60-120 mesh), $\mathrm{CH}_{2} \mathrm{Cl}_{2} / \mathrm{CH}_{3} \mathrm{OH}(18: 2)$ to give a red coloured solid. Recrystallization from $\mathrm{CH}_{2} \mathrm{Cl}_{2} / \mathrm{CH}_{3} \mathrm{OH}$ afforded dark red coloured crystals. Yield: $0.56 \mathrm{~g}$ (68\%), m.p. $140-145^{\circ} \mathrm{C} ;[\alpha]=+96 \cdot 82\left(0 \cdot 1 \mathrm{c}, \mathrm{CHCl}_{3}\right)$; Anal. Calcd. for $\mathrm{C}_{38} \mathrm{H}_{38} \mathrm{Fe}_{2} \mathrm{~N}_{2} \mathrm{O}_{2} \mathrm{Se}_{2}: \mathrm{C}, 55 \cdot 38 ; \mathrm{H}$, 4.64; N, 3.40\%. Found: C, 55.12, H, 3.98; N, 3.28\%; IR (KBr): 3326, 3084, 3027，2967，2924，1682, 1527, 1449, 1374, 1263, 821, $699 \mathrm{~cm}^{-1}$; ${ }^{1} \mathrm{H}$ NMR $\left(\mathrm{CDCl}_{3}\right) \delta 1.60(d, 6 \mathrm{H}), 4.09(q, 3 \mathrm{H}), 4.24(s, 10 \mathrm{H})$, 4.32-5.28 (m, 6H), 5.29 (d, 2H), 7.26-7.35 (m, 10H); ${ }^{13} \mathrm{C} \mathrm{NMR}\left(\mathrm{CDCl}_{3}\right): \delta 21.748 .5,67 \cdot 83,68 \cdot 41,69 \cdot 28$, $70.43,70 \cdot 44,76 \cdot 07,126.42,127.4,128.7,143.6$, $169 \cdot 3 ;{ }^{77} \mathrm{Se}$ NMR $\left(\mathrm{CDCl}_{3}\right) \delta 455,460$; ES-MS: $\mathrm{m} / \mathrm{z}$ $823\left(M^{+}\right)$.

$2.1 \mathrm{~h}$ Synthesis of 1-bromo-2-bromomethylnaphtalene (20): ${ }^{17} \quad \mathrm{~A} \mathrm{CCl}_{4}$ solution $(150 \mathrm{ml})$ of 2-methylbromonaphthalene $(9.95 \mathrm{~g}, 7 \mathrm{ml}, 45 \mathrm{mmol})$ and $\mathrm{N}$ bromosuccinamide $(8.9 \mathrm{~g}, 50 \mathrm{mmol})$ was refluxed in the presence of benzoyl peroxide $(0.1 \mathrm{~g})$ for $16 \mathrm{~h}$ under $\mathrm{N}_{2}$. The solid formed by the reaction was filtered off and the solvent removed in vacuo. Recrystallization from hexane at $0^{\circ} \mathrm{C}$ afforded a white crystalline solid, 20. Yield: 12.96 g (96\%), m.p. 106-107 (lit. 107-109 $\left.{ }^{\circ} \mathrm{C}\right),{ }^{17}$ Anal. Calcd. for $\mathrm{C}_{11} \mathrm{H}_{8} \mathrm{Br}_{2}$ : C, 44.06; H, 2.69\%; Found: C, 43.99; H, 2.38\%; GC retention time $=12.26 \mathrm{~min}$; IR (KBr) 3058, 2954, 2822, 1690, $1512,1466,1287,1045,821 \mathrm{~cm}^{-1},{ }^{1} \mathrm{H}$ NMR $\left(\mathrm{CDCl}_{3}\right)$ $\delta 4.78(\mathrm{~s}, 2 \mathrm{H}), 7.26-7.78(\mathrm{~m}, 4 \mathrm{H}), 8.12-8.28(\mathrm{~m}$, 2H); GC-MS (\% abundance), 301 (50), 221 (100), 222 (70).

$2.1 \mathrm{i}$ Synthesis of 1-bromo-2-(N,N-dimethylaminomethyl)naphthalene (21): ${ }^{18}$ To a THF solution (100 ml) of 1-bromo-2-bromomethylnaphthalene; 20 $(3 \mathrm{~g}, 10 \mathrm{mmol})$ and dimethyl amine $(0.9 \mathrm{~g}, 20 \mathrm{mmol}$, $4.0 \mathrm{ml}$ (40\% aqueous solution) were added dropwise at $0^{\circ} \mathrm{C}$ under $\mathrm{N}_{2}$ and stirring was continued for a further $1 \mathrm{~h}$ at $0^{\circ} \mathrm{C}$. Then the reaction mixture was refluxed for $19 \mathrm{~h}$. The reaction mixture was poured into cold water and extracted with $3 \times 25 \mathrm{ml}$ of $\mathrm{Et}_{2} \mathrm{O}$, dried over $\mathrm{Na}_{2} \mathrm{SO}_{4}$, concentrated in vacuo at $45^{\circ} \mathrm{C}$ and purified by column chromatography using $\mathrm{SiO}_{2}(60$
120 mesh) and petroleum ether $\left(60-80^{\circ} \mathrm{C}\right) /$ ethyl acetate $(6: 4)$ to give light yellow coloured oil of 21. Yield: $2.27 \mathrm{~g}(86 \%)$; GC retention time $=13.17 \mathrm{~min}$; ${ }^{1} \mathrm{H}$ NMR $\left(\mathrm{CDCl}_{3}\right) \delta 2.25(s, 6 \mathrm{H}), 3.68(s, 2 \mathrm{H}), 7.42$ $(t, 2 \mathrm{H}), 7.56(t, 2 \mathrm{H}) 8.38(d, 1 \mathrm{H}) ; 8.17(d, 1 \mathrm{H}), \mathrm{IR} v_{\max }$ (neat): 3058, 2954, 2822, 1690, 1512, 1466, 1287, $1045,821 \mathrm{~cm}^{-1}$; GC-MS (\% abundance), 263, 221 (100); 219 (70).

\section{$2.1 \mathrm{j}$ Synthesis of bis[2-(N,N-dimethylaminomethyl-} naphthyl]diselenide (13): To a solution of 21 $(1.84 \mathrm{~g}, 10 \mathrm{mmol})$ in dry $\mathrm{Et}_{2} \mathrm{O}(75 \mathrm{ml})$ was added dropwise $n$-BuLi $(7.7 \mathrm{ml}, 12.3 \mathrm{mmol}, 1.6 \mathrm{M}$ solution in hexane) under $\mathrm{N}_{2}$ at $-78^{\circ} \mathrm{C}$ over a period of $10 \mathrm{~min}$. The mixture was stirred for $30 \mathrm{~min}$ at this temperature and $30 \mathrm{~min}$ at $0^{\circ} \mathrm{C}$. Selenium powder $(0.79 \mathrm{~g}$, $10 \mathrm{mmol}$ ) was added portion wise at $0^{\circ} \mathrm{C}$. The reaction mixture was stirred further for $5 \mathrm{~h}$ from $0^{\circ} \mathrm{C}$ to room temperature. The reaction mixture was poured into cold aqueous saturated $\mathrm{NaHCO}_{3}$ and $\mathrm{O}_{2}$ was passed at a moderate rate for $30 \mathrm{~min}$. The organic phase was separated, dried over $\mathrm{Na}_{2} \mathrm{SO}_{4}$ and filtered. The filtrate was concentrated to $15 \mathrm{ml}$. A light yellow solid, which precipitated out from the resulting solution on cooling, was filtered out. The compound was recrystallized from ethanol to give yellow needles. Yield: $1.2 \mathrm{~g} \mathrm{(46 \% ),} \mathrm{m.p.} 165-167^{\circ} \mathrm{C}$; Anal. Calcd. for $\mathrm{C}_{26} \mathrm{H}_{28} \mathrm{~N}_{2} \mathrm{Se}_{2}: \mathrm{C}, 59 \cdot 34 ; \mathrm{H}, 5 \cdot 36 ; \mathrm{N}, 5.32 \%$; Found: C, 58.76, H, 5.25, N, 5.67\%; IR (KBr): 3072, 2967, 2927, 2769, 1506, 1460, 1262, 1032, $821 \mathrm{~cm}^{-1}$; ${ }^{1} \mathrm{H} \mathrm{NMR}\left(\mathrm{CDCl}_{3}\right) \delta 2.45(s, 12 \mathrm{H}), 3.98(s, 2 \mathrm{H}), 7.42$ $(t, 2 \mathrm{H}), 7.58-7.71(m, 4 \mathrm{H}), 7.98(t, 4 \mathrm{H}), 8.92(d$, $2 \mathrm{H}) ;{ }^{13} \mathrm{C} \mathrm{NMR}\left(\mathrm{CDCl}_{3}\right) \delta 24.59,125.05,126.39$, $127 \cdot 88,127.93,128 \cdot 88,129 \cdot 42,129 \cdot 89,132 \cdot 38$, 135.87, $142 \cdot 55 .{ }^{77} \mathrm{Se} \mathrm{NMR}\left(\mathrm{CDCl}_{3}\right) \delta 356$; ES-MS $(\mathrm{m} / \mathrm{z}) 527\left(M^{+}\right)$.

$2.1 \mathrm{k}$ Synthesis of bis(2,4-dinitrophenyl) diselenide (14): ${ }^{19}$ Sodium $(0.23 \mathrm{~g}, 10 \mathrm{mmol})$, selenium powder $(0.8 \mathrm{~g}, 10 \mathrm{mmol})$ and naphthalene $(0.12 \mathrm{~g}, 1 \mathrm{mmol})$ were refluxed in dry THF $(15 \mathrm{ml})$ under $\mathrm{N}_{2}$ for overnight. The colour of the reaction mixture turned to brown. To this reaction mixture, 2,4-dinitro-chloro-benzene $(2.02 \mathrm{~g}, 10 \mathrm{mmol})$ in dry THF $(6 \mathrm{ml})$ was added at $0^{\circ} \mathrm{C}$. The stirring was continued for an additional $1 \mathrm{~h}$, the product was filtered off, and washed with ether $4 \times 20 \mathrm{ml}$ and then with hexane. It was recrystallized from $\mathrm{CH}_{3} \mathrm{OH}$ and dried under vacuum to afford a yellow crystalline solid. Yield: $1.87 \mathrm{~g}(76 \%)$, m.p. 262-264 (lit. 268 ${ }^{\circ} \mathrm{C}$ ); Anal. Calcd. for $\mathrm{C}_{12} \mathrm{H}_{6} \mathrm{~N}_{4} \mathrm{O}_{8} \mathrm{Se}_{2}$ : C, 29.30; H, 1.23; N, 11.38\%; Found: C, 28.86, H, 
1.16, N, 11.98\%; IR (KBr): v, 3067, 2936, 2857, $1618,1622,1542,1448,758 \mathrm{~cm}^{-1} ;{ }^{1} \mathrm{H}$ NMR $\left(\mathrm{CDCl}_{3}\right)$ $\delta 7.87(d, 2 \mathrm{H}), 8.76(d, 2 \mathrm{H}), 8.98(s, 2 \mathrm{H}) ;{ }^{13} \mathrm{C} \mathrm{NMR}$ $\left(\mathrm{CDCl}_{3}\right) \delta 122 \cdot 14,128 \cdot 51,136 \cdot 37,136 \cdot 88,148 \cdot 29$, 147.64. ${ }^{77} \mathrm{Se} \mathrm{NMR}\left(\mathrm{CDCl}_{3}+\mathrm{DMSO}\right) \delta 525$. ES-MS: $\mathrm{m} / z 348\left(M^{+}\right), 3413,258,239,213,183,155,129$.

\subsection{Kinetic analysis}

The reactions of model compounds with benzenethiol $(\mathrm{PhSH})$ and $\mathrm{H}_{2} \mathrm{O}_{2}$ were studied in methanol by following the appearance of the disulphide absorption at $305 \mathrm{~nm}$, at $25^{\circ} \mathrm{C} .{ }^{10 \mathrm{~b}}$ Each initial velocity was measured at least six times and calculated from the first $5-10 \%$ of the reaction. For the peroxidase activity, the rates were corrected for the background reaction between $\mathrm{H}_{2} \mathrm{O}_{2}$ and $\mathrm{PhSH}$. The actual concentration of $\mathrm{PhSH}$ in the kinetic apparatus was measured from the $305 \mathrm{~nm}$ absorbance, and rates were corrected for any variation in the concentration of $\mathrm{PhSH}$. The molar extinction coefficient of $\mathrm{PhSSPh}$ $\left(\varepsilon=1.24 \times 10^{-3} \mathrm{M}^{-1} \mathrm{~cm}^{-1}\right)$ at the wavelength was much larger than that of PhSH $\left(\varepsilon=9 \mathrm{M}^{-1} \mathrm{~cm}^{-1}\right)$. The concentration of $\mathrm{PhSH}$ was, therefore, calculated from the absorbance $(a)$ according to the following equation: $C=\left(\varepsilon_{1} C_{0}-2 a\right) /\left(\varepsilon_{2}-2 \varepsilon_{2}\right) \approx C_{0}-2 a / \varepsilon_{1}$. The initial reduction rate of $\mathrm{H}_{2} \mathrm{O}_{2}\left(v_{0}\right)$ was then determined by $1 / v_{0}$ vs $1 /[\mathrm{PhSH}]$ plots using the Grapher program. Concentration of the $\mathrm{H}_{2} \mathrm{O}_{2}$ stock was determined by permanganate titration. To investigate the dependence of rate on substrate concentrations, the reaction rates were determined at several concentrations of one substrate while keeping the concentration of the other constant. The LineweaverBurk plots were obtained using the Grapher 1.09 version, 2D-Graphing System for Windows program. ${ }^{20}$ For each set of experiments a straight line was drawn by choosing the best fit method.

\section{Results and discussion}

\subsection{Synthesis}

N-Phenylferrocenecarboxamide (15), N-tert-butylferrocenecarboxamide (16) and $(S)$-N-phenethylferrocenecarboxamide (17) were synthesized from the ferrocenoyl chloride and corresponding primary amines in the presence of catalytic amount of triethyl amine. Ferrocenoyl chloride was generated in situ by the reaction of ferrocene carboxylic acid and oxalyl chloride (scheme 2). Initially the lithiation of ferro- cenamides (15-17) with $n$-BuLi was attempted in diethyl ether. However, the reaction was unsuccessful.

Lithiation of ferrocenecarboxamides was successful in THF. Addition of selenium to the dilithiated species $(\mathbf{1 8 a}-\mathbf{c})$ provided a dark red coloured solution of dilithium areneselenolates $(\mathbf{1 9 a}-\mathbf{c})$ at low temperature. Oxidation of 19a using aqueous $\mathrm{K}_{3} \mathrm{Fe}(\mathrm{CN})_{6}$ gave the corresponding diselenide (10) in 68\% yields. Similarly oxidative workup of $19 b$ and $19 c$ provided corresponding diselenides (11 and 12) in good yields (71-79\%). These diselenides were purified by column chromatography.

Synthesis of diselenide (13) was accomplished by the well-established organolithium route (scheme 3 ). Bromine/lithium exchange with $n$ - $\mathrm{BuLi}$ in $\mathrm{Et}_{2} \mathrm{O}$ proceeded smoothly to give the desired aryllithium (22). This reagent slowly reacts with elemental selenium to give aryllithium selenolate (23). Oxidation of $\mathbf{2 3}$ provided the desired diselenide. Diselenide (14) was synthesized by the reaction of disodium diselenide $\left(\mathrm{Na}_{2} \mathrm{Se}_{2}\right)$ and 2,4-dinitro-1-chlorobezene. ${ }^{19}$

\subsection{Spectroscopic study}

Ferrocenecarboxamide-based diselenides (10-12) show two closely spaced signals in the ${ }^{77} \mathrm{Se}$ NMR spectra (vide supra, see experimental section) and the mean values are reported here for comparison. The ${ }^{77} \mathrm{Se}$ NMR signal for compound $\mathbf{1 3}$ was observed at $356 \mathrm{ppm}$ and this is shifted upfield compared to related diselenide 4 (484 ppm), phenyl analogue, 2 (430 ppm), and bis[2-(N,N-dimethylaminomethyl)ferrocenyl] diselenide $(576 \mathrm{ppm}){ }^{10 \mathrm{~d}, 21,22}$ The downfield shift of the ${ }^{77}$ Se NMR peaks is due to strong S...N nonbonding interaction as widely accepted, although the values for the shift do not correspond exactly to the strength of the Se...N interaction. Thus, upfield shift in $\mathbf{1 3}$ shows the presence of weak intramolecular Se...N intearaction compared to diselenides 3 and 4 . The ${ }^{77} \mathrm{Se}$ NMR chemical downfield shift for diselenide 14 with two electron-withdrawing nitro groups is $525 \mathrm{ppm}$.

In the IR spectra, $v_{\mathrm{NH}}$ vibrations for diselenides 10-12 are 3302,3342 and $3326 \mathrm{~cm}^{-1}$ respectively. These values are observed at frequencies slightly higher than their precursors 15-17 (3294 and 3315, $3310 \mathrm{~cm}^{-1}$ ). Similarly $v_{\mathrm{C}=\mathrm{O}}$ vibrations for diselenides (10-12) are shifted slightly upper frequency range $12-40 \mathrm{~cm}^{-1}$ compared to $\mathbf{1 5}-\mathbf{1 7}$ and indicating the presence of interaction between selenium and oxygen of the amide group. 


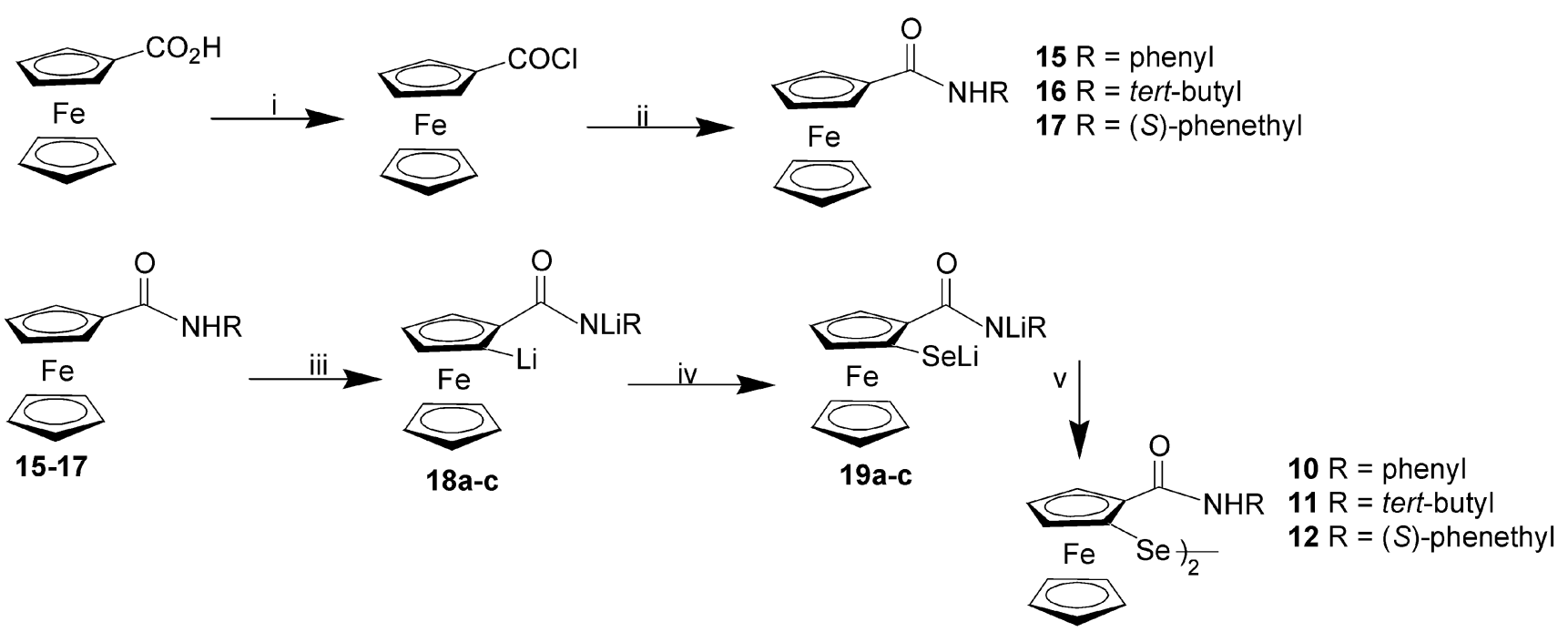

Reagents and conditions: (i) $n$-BuLi, THF, $-15^{\circ} \mathrm{C}, 30 \mathrm{~min}$; (ii) Se powder, $0^{\circ} \mathrm{C}, 2 \mathrm{~h}$; (iii) aqueous $\mathrm{K}_{3} \mathrm{Fe}(\mathrm{CN})_{6}$; (iv) $t$-BuLi, $\mathrm{THF}, 0^{\circ} \mathrm{C}, 30 \mathrm{~min}$; (v) Se powder, $0^{\circ} \mathrm{C}, 1 \mathrm{~h}$; (vi) aqueous $\mathrm{K}_{3} \mathrm{Fe}(\mathrm{CN})_{6}$.

Scheme 2. Synthesis of diselenides (10-12) and their precursors (15-17).

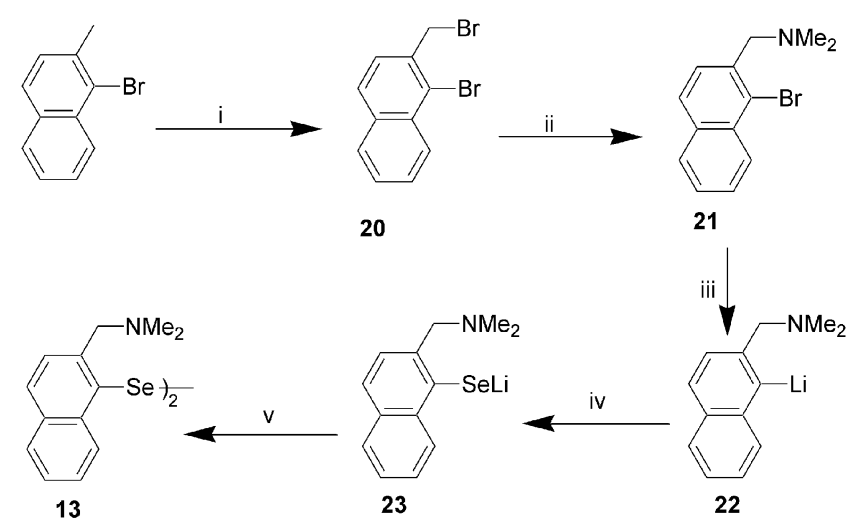

Reagents and conditions: (i) NBS, $\mathrm{CCl}_{4}$, reflux, $24 \mathrm{~h}$; (ii) aqueous $\mathrm{HNMe}_{2}, \mathrm{THF}$, reflux; (iii) $n$-BuLi, $\mathrm{Et}_{2} \mathrm{O},-78^{\circ} \mathrm{C}$, $30 \mathrm{~min}$; (iv) Se powder, $0^{\circ} \mathrm{C}, 5 \mathrm{~h}$; (v) $\mathrm{O}_{2}$, aqueous $\mathrm{NaHCO}_{3}$

Scheme 3. Synthesis of diselenide (13) and bromonaphthylamine (21).

\subsection{Thiol peroxidase-like activity}

Catalytic activity was studied according to the thiol assay method reported by Tomoda et $a l^{10 \mathrm{~b}}$ using benzenethiol $(\mathrm{PhSH})$ as a glutathione alternative. The thiol assay has an advantage over the coupled assay due to use of a solvent system which is more compatible with diorganodiselenides. ${ }^{23}$ The initial rates $\left(v_{0}\right)$ for the reduction of $\mathrm{H}_{2} \mathrm{O}_{2}(3.75 \mathrm{mM})$ by thiol $(1 \mathrm{mM})$ in the presence of various catalysts $(0.01 \mathrm{mM})$ were determined in methanol medium by monitoring the UV absorption at $305 \mathrm{~nm}$ due to the formation of diphenyl disulfide $(\mathrm{PhSSPh})$. The catalytic activities of the compounds are summarised in table 1 .

Activities of some known catalysts have been carried out for comparison with those of the new diselenides prepared in this study. The uncatalysed reduction rate is very slow $\left(v_{0}=0.15 \pm 0.04 \mu \mathrm{M} \mathrm{min}{ }^{-1}\right)$, but a considerable enhancement in the rate is observed when the simple diphenyl diselenide was added $\left(v_{0}=\right.$ $\left.0.58 \pm 0.17 \mu \mathrm{M} \mathrm{min}^{-1}\right)$. Acitivites of diselenides 1, 3 and 4 (entries a, b, c) are in close agreement with the reported values (table 1). ${ }^{10 \mathrm{~d}}$ Diselenides 10-12 show low reaction rates $\left(v_{0}=13.38 \pm 0.2,15.97 \pm 0.3\right.$, $18.98 \pm 0 \cdot 1 \mu \mathrm{M} \mathrm{min}^{-1}$, entries d, e, f) for $\mathrm{H}_{2} \mathrm{O}_{2}$ oxidation of benzenethiol. These diselenides show 40fold lower activity than the ferrocene-based diselenides 1-2 $\left(v_{0}=574.01 \pm 24 \mu \mathrm{M} \mathrm{min}^{-1}\right)$. However, these diselenides are better catalysts than simple diferrocenyldiselenide $\left(v_{0}=3 \cdot 39 \pm 0 \cdot 3 \mu \mathrm{M} \mathrm{min}^{-1}\right)$ and benzamide based diselenide, which is inactive. ${ }^{10 \mathrm{~d}}$ Diselenide (13), with a basic amino group, is found to be an efficient catalyst $\left(279.8 \pm 10 \mu \mathrm{M} \mathrm{min}{ }^{-1}\right.$, entry g, table 1), which shows $\sim 10$-fold higher activity than the corresponding phenyl based diselenide $\mathbf{3}$ (28.38 $\pm 4 \mu \mathrm{M} \mathrm{min}^{-1}$ entry $\mathrm{b}$, table 1$)$. There was no noticeable effect on the reduction rate when only bromo naphthylamine (21) $\left[v_{0}=0.78 \pm 0.2 \mu \mathrm{M} \mathrm{min}^{-1}\right.$ entry i) is used as catalyst. It is interesting to note that the diselenide $\mathbf{4}$ has the basic amino group in close proximity to selenium and is inactive. In diselenide 4 basic amino groups are in conjugation with 
selenium whereas in $\mathbf{1 3}$, there is no such conjugation present. It is worth mentioning here that the simple dinaphthyl diselenide $\left(5.4 \mu \mathrm{M} \mathrm{min}^{-1}\right)$ shows nearly 10-fold higher activity than diphenyl diselenide $\left(0.55 \mu \mathrm{M} \mathrm{min}^{-1}\right){ }^{10 \mathrm{~d}}$ Diselenide 14 with two nitro groups exhibits $170 \cdot 66 \pm 9 \mu \mathrm{M} \mathrm{min}^{-1}$ (entry h) activity. The introduction of nitro group in ortho position to selenium in ebselen (2-phenyl-1,2-benzisoselenazol$3(2 \mathrm{H}$-one)) has been shown to strongly enhance GP $x$ activity and it has been suggested that influence of the elctronic effects on selenium by the interaction of nitro group may be responsible for the high GP $x$ activity of nitrated ebselen. ${ }^{24}$

\subsection{Cyclic voltammetric study}

The redox properties of diselenides 10-12 and their precursors 15-17 were investigated by cyclic voltammetry in $\mathrm{CH}_{3} \mathrm{CN}$ solution. A representative cyclic voltammogram for diselenide $\mathbf{1 0}$ shown in figure 1, reveals a reversible redox wave of equal intensity

Table 1. The initial reduction rate $\left(v_{0}\right)$ for diselenides.

\begin{tabular}{lccl}
\hline Entry & Compounds & $\left(\mathrm{v}_{0}\right) \mu \mathrm{M} \mathrm{min}^{-1}$ & Reference \\
\hline $\mathrm{a}$ & $\mathbf{1}$ & $574 \cdot 01 \pm 24$ & $10 \mathrm{~d}$ \\
$\mathrm{~b}$ & $\mathbf{3}$ & $28 \cdot 38 \pm 4$ & $10 \mathrm{~d}$ \\
$\mathrm{c}$ & $\mathbf{4}$ & Inactive & $10 \mathrm{~d}$ \\
$\mathrm{~d}$ & $\mathbf{1 0}$ & $13 \cdot 38 \pm 0 \cdot 2$ & This work \\
$\mathrm{e}$ & $\mathbf{1 1}$ & $15 \cdot 97 \pm 0 \cdot 3$ & This work \\
$\mathrm{f}$ & $\mathbf{1 2}$ & $18 \cdot 98 \pm 0 \cdot 1$ & This work \\
$\mathrm{g}$ & $\mathbf{1 3}$ & $279 \cdot 8 \pm 10$ & This work \\
$\mathrm{h}$ & $\mathbf{1 4}$ & $170 \cdot 66 \pm 9$ & This work \\
$\mathrm{i}$ & $\mathbf{2 1}$ & $0.78 \pm 0 \cdot 2$ & This work \\
\hline
\end{tabular}

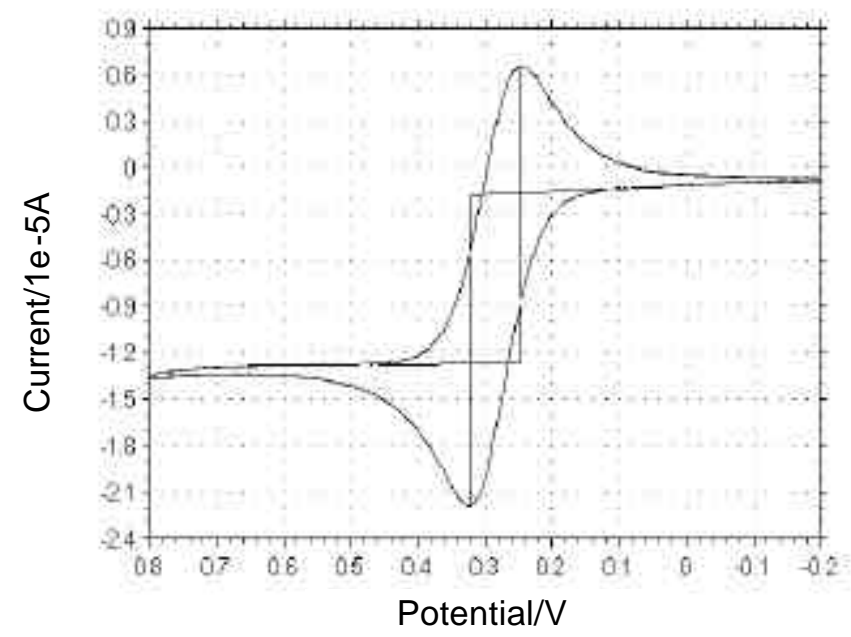

Figure 1. Cyclic voltammogram of compounds $\mathbf{1 0 .}$ with half-wave potential $\left(E_{1 / 2}\right)$ value of $+311 \mathrm{mV}$. Half-wave potentials values for diselenide 10-12 are 311, 292 and $287 \mathrm{mV}$ and for their ligands $\mathbf{1 5 - 1 7}$ are 228, 206, $204 \mathrm{mV}$ respectively.

$E_{1 / 2}$ values for these compounds 10-12 are considerably more positive than the corresponding value for ferrocene. This may be due to the strong electronwithdrawing nature of the amide groups, which are bonded directly to the $\mathrm{Cp}$ ring, making the oxidation more difficult than that of unsubstituted ferrocene. ${ }^{25}$ Diselenides (10-12) have higher oxidation potentials than their precursors.

\section{Conclusion}

In summary, a comparison of thiol peroxidase-like activities of various diorganoselenides has been made. The noticeable observations are as follows: (i) ferrocenecarboxamides based diselenide (10-12) show better activity compared to the benzamide based diselenides; (ii) diselenide (13) with an amino group without conjugation with the aromatic substrate shows better activity than diselenide $\mathbf{4}$, which has an amino group in conjugation with the aromatic substrate.

\section{Acknowledgments}

This work was supported by the Department of Science and Technology, and the Council of Scientific and Industrial Research, Government of India, New Delhi.

\section{References}

1. (a) Schwarz K and Foltz C M 1957 J. Am. Chem. Soc. 79 3292; (b) Flohé L, Loschen G, Günzler W A and Eichele E 1972 Hoppe-Seyler's Z. Physiol. Chem. 353 987

2. Ren B, Huang W, Åkesson B and Ladenstein R 1997 J. Mol. Biol. 268869

3. (a) Mugesh G and Singh H B 2000 Chem. Soc. Rev. 29 347; (b) Mugesh G, du Mont W-W and Sies H 2001 Chem. Rev. 101 2125; (c) Mugesh G and du Mont WW 2001 Chem. Eur. J. 71365

4. (a) Müller A, Cadenas E, Graf P and Sies H 1984 Biochem. Pharmacol. 33 3235; (b) Wendel A, Fausel M, Safayhi H, Tiegs G and Otter R 1984 Biochem. Pharmacol. 33 3241; (c) Back T G and Dyck B P 1997 J. Am. Chem. Soc. 119 2079; (c) Roy G, Nethaji M and Mugesh G 2004 J. Am. Chem. Soc. 1262712

5. Zade S S, Tripathi S K, Singh H B and Wolmershäuser G 2004 Eur. J. Org. Chem. 3857 
6. (a) Back T G and Moussa Z 2003 J. Am. Chem. Soc. 125 13455; (b) Back T G, Moussa Z and Parvez M 2004 Angew. Chem., Int. Ed. Engl. 431268

7. Zade S S, Singh H B and Butcher R J 2004 Angew. Chem., Int. Ed. Engl. 434513

8. Wu Z-P and Hilvert D 1990 J. Am. Chem. Soc. 112 5647

9. Soda K 1992 Phosphorus, Sulfur and Silicon 67461

10. (a) Wilson S R, Zucker P A, Huang R-R C and Spector A 1989 J. Am. Chem. Soc. 111 5936; (b) Iwaoka M and Tomoda S 1994 J. Am. Chem. Soc. 116 2557; (c) Wirth T 1998 Molecules 3 164; (c) Mugesh G, Panda A, Singh H B, Punekar N S and Butcher R J 1998 Chem. Commun. 2227; (d) Mugesh G, Panda A, Singh H. B, Punekar N S and Butcher R J 2001 J. Am. Chem. Soc. 123 839; (e) Kumar S, Kandasamy K, Singh H B, Wolmershäuser G and Butcher R J 2004 Organometallics 23 4199; (f) Zhang X, Xu H, Dong Z, Wang Y, Liu J and Shen J 2004 J. Am. Chem. Soc. 12610556

11. (a) Engman L, Andersson C, Morgenstern R, Cotgreave I A, Andersson C-M and Hallbergd A 1994 Tetrahedron 50 2929; (b) Cotgreave I A, Moldéus P, Brattsand R, Hallberg A, Andersson C-M and Engman L 1992 Biochem. Pharmacol. 43793

12. Mugesh G, Panda A, Kumar S, Apte S D, Singh H B and Butcher R J 2002 Organometallics 21884
13. Kumar S, Tripathi S K, Singh H B and Wolmershäuser G 2004 J. Organomet. Chem. 6893064

14. Reeves P C 1973 Org. Synth., Coll. Vol. 6625

15. Oberhoff M, Duda L, Karl J, Mohr R, Erker G, Frohlich R and Grehl M 1996 Organometallics 154005

16. van Staveren D R, Weyhermüller T and Nolte N M 2003 J. Chem. Soc., Dalton Trans. 210

17. (a) Spring D R, Krishnan S, Blackwell H E and Schreiber S L 2002 J. Am. Chem. Soc. 124 1354; (b) Cornejo J J, Ghodsi S, Johnson R D, Woodling R and Rickburn B 1983 J. Org. Chem. 483869

18. Robert L G and Charles R H 1967 J. Am. Chem. Soc. 892297

19. Syper L and Mlochowski J 1988 Tetrahedron 446119

20. Schmitz D, Smith D and Wall W 1993 Grapher 1.09, 2D Graphical System; Golden Software, Inc

21. Panda A, Mugesh G, Singh H B and Butcher R J 1999 Organometallics 181986

22. Kaur R Singh H B and Patel R P 1996 J. Chem. Soc., Dalton Trans. 2719

23. You Y, Ahsan K and Detty M R 2003 J. Am. Chem. Soc. 1254918

24. Parnham M J, Biederman J, Bittner C, Dereu N, Leyck S and Wetzig H 1989 Agents Actions 27306

25. Burgess M R and Morley C P 2001 J. Organomet. Chem. 623101 